Biol. Stud. 2013: 7(3); 115-132 • DOI: https://doi.org/10.30970/sbi.0703.312

www.http://publications.Inu.edu.ua/journals/index.php/biology

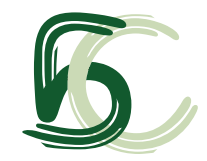

UDC: $579.846 .2: 22$

\title{
IDENTIFICATION OF SULFATE-REDUCING BACTERIA STRAINS OF HUMAN LARGE INTESTINE
}

Ivan V. Kushkevych

Faculty of Pharmacy, University of Veterinary and Pharmaceutical Sciences Brno 1/3, Palackeho, CZ-61242 Brno, Czech Republic e-mail: ivan.kushkevych@gmail.com

The sulfate-reducing bacteria have been isolated from human intestine. These bacteria are identified by their morphological, physiological and biochemical characteristics as the Desulfovibrio sp. and Desulfomicrobium sp. according to Bergey's Manual of Determinative Bacteriology. Growth of the isolated strains of bacteria has been studied under various conditions including types of media, effect of oxygen, $\mathrm{pH}$, and temperature. Bacterial growth in the modified Kravtsov-Sorokin's medium, and process of dissimilatory sulfate reduction by the selected strains of bacteria have been investigated. All obtained bacterial cultures used sulfate and lactate intensively as well as produced hydrogen sulfide and acetate in the medium. The Desulfovibrio sp. strain Vib-7 produced the highest concentration (up to $3.23 \mathrm{mM}$ ) of hydrogen sulfide, while the bacteria used about $99 \%$ of sulfate ions presented in the medium. This strain also produced the highest concentration of acetate ions (up to $15.87 \mathrm{mM}$ ) on the fifth day of cultivation. Among the studied Desulfomicrobium sp. strains, the highest concentration of hydrogen sulfide was produced by the Desulfomicrobium sp. strain Rod-9, and the highest concentration of acetate ions was produced by the Desulfomicrobium sp. strain Rod-4.

Keywords: sulfate-reducing bacteria, Desulfovibrio, Desulfomicrobium, identification, sulfates, hydrogen sulfide.

\section{INTRODUCTION}

Sulfate-reducing bacteria Desulfovibrio, Desulfomicrobium, Desulfobulbus, Desulfobacter, Desulfomonas and Desulfotomaculum genera make an important component of human intestinal microbiocenosis [2, 15, 19, 21, 23]. An increased number of these microorganisms can be found in people with periodontitis, inflammatory bowel diseases, ulcerative colitis, rheumatic diseases and many other diseases $[6,8,9,16$, $18,20,24]$. Some scientists also suggest that the sulfate-reducing bacteria (SRB) might cause of some forms of colon cancer, taking into account that these microorganisms produce hydrogen sulfide affecting the intestinal cells metabolism causing various diseases $[6,15,16,22,24,28]$. This is the main reason why it is necessary to study SRB in more detail. 
The sulfate-reducing bacterial cells are spherical, oval, rod-shaped, spiral or vibrioshaped with a diameter of 0.4-3.0 $\mu \mathrm{m}$. The cells can be either single, in pairs or aggregates. The cells may also form a single row of multicellular filaments [2]. Most cells of the genera of the SRB are Gram-negative, whereas the filamentous and spore-forming microorganisms are stained Gram-positive. The SRB genera are all strict anaerobes [11].

The sulfate-reducing bacteria reduce sulfate ions and in some cases they can reduce sulfur to hydrogen sulfide. They oxidize organic compounds completely, forming carbon dioxide or incompletely, with the formation of acetate as an end product. A lot of SRB species use $\mathrm{H}_{2}$, lactate, fatty acids, ethanol, dicarboxylic acids and other organic compounds as electron donors. Some SRB species can grow autotrophically using $\mathrm{H}_{2}$, $\mathrm{CO}_{2}$ and sulfate. The bacteria can use ammonium salts as nitrogen sources [2, 3]. SRB species can assimilate molecular nitrogen [23].

According to Bergey's Manual of Determinative Bacteriology (ninth edition), the dissimilatory sulfate- or sulfur-reducing bacteria belong to the seventh group. This group, in turn, is divided into four subgroups [11]:

1. The first subgroup contains one Desulfotomaculum genus that integrates all spore-forming sulfate-reducing bacteria.

2. The second subgroup contains asporogenous sulfate-reducing bacteria that oxidize organic compounds incompletely producing acetate. Few species are able to use sulfur as an electron acceptor. The subgroup includes Desulfobulbus, Desulfomicrobium, Desulfomonas, Desulfovibrio, Thermodesulfobacterium genera which are all Gram-negative.

3. The third subgroup contains asporogenous sulfate-reducing bacteria that oxidize organic substrates completely to $\mathrm{CO}_{2}$. The subgroup includes Desulfobacter, Desulfobacterium, Desulfococcus, Desulfomonile, Desulfonema, Desulfosarcina genera. In this case sulfur is not used as an electron acceptor.

4. The fourth subgroup contains asporogenous bacteria that reduce sulfur. They oxidize organic substrates completely to $\mathrm{CO}_{2}$. This subgroup includes Desulfurella and Desulfuromonas genera. These bacteria use sulfur as an electron acceptor. Growth in media containing sulfate or other sulfur oksoanions was not observed.

It is regarded that the bacterial species, composition and number on the surface of the intestinal mucosa differ from that of the composition and number of microorganisms found on the intestinal lumen [21, 24, 28]. These bacteria are in close interaction with each other. It was established that SRB can completely displace methanogenic microorganisms of the intestine in the process of $\mathrm{H}_{2}$ competition. This competition for molecular hydrogen between SRB and methanogens largely depends on the presence and quantity of sulfate in the gut [8, 9]. Adding sulfate and sulfated mucopolysaccharides to fecal suspensions which contain metabolically active products of the SRB, stimulates the formation of hydrogen sulfide and inhibits the intensity of the methanogenesis $[2,10]$.

The sulfate-reducing bacteria can form biofilms on the surface of the epithelial cells of the large intestine [21]. These biofilms are often resistant to antimicrobial substances therefore it is an interesting area of study. It is of vital importance to obtain new strains of the SRB from different people, identify them and then study their growth, physiological and biochemical properties. Aside from that, process of dissimilatory sulfate reduction by SRB and the production of hydrogen sulfide should be investigated in order to clarify the etiological role of these bacteria in the development of various diseases. The data

ISSN 1996-4536 • Біологічні Студії / Studia Biologica • 2013 • Том 7/№3 • С. 115-132 
on the concentration of hydrogen sulfide, produced by the isolates is supposed to help in establishing and assessing a toxicity effect of hydrogen sulfide on the epithelial cells of the human intestine. Such studies might help in predicting the development of diseases in the gastrointestinal tract, by providing further details on the etiology of bowel diseases which are very important for the clinical diagnosis of these disease types.

The aim of this study was to obtain the sulfate-reducing bacteria from the colon feces of healthy people, and identify some strains of the bacteria by their morphological, physiological and biochemical characteristics.

\section{MATERIAL AND METHODS}

Object of the study. Strains of sulfate-reducing bacteria which were obtained from human large intestine at the Microbiology, Virology and Immunology Department of the Danylo Halytsky Lviv National Medical University. As control, sulfate-reducing bacteria Desulfovibrio desulfuricans strain IMV K-6, isolated from Yavoriv lake water and identified at the Microbiology Department of Ivan Franko National University of Lviv were used.

Obtaining of the bacterial cultures. One gram of feces was suspended in $9 \mathrm{ml}$ of the modified Kravtsov-Sorokin's liquid medium [13]. Before, the medium was heated in boiling water for $30 \mathrm{~min}$ in order to obtain an oxygen-free medium and cooled to $+30^{\circ} \mathrm{C}$ temperature. After cooling, decimal dilutions were made to $10^{-12}$ in a series of tubes containing Kravtsov-Sorokin's liquid medium of such composition (g/l): $\mathrm{Na}_{2} \mathrm{SO}_{4}-0.5$; $\mathrm{KH}_{2} \mathrm{PO}_{4}-0.3 ; \mathrm{K}_{2} \mathrm{HPO}_{4}-0.5 ;\left(\mathrm{NH}_{4}\right)_{2} \mathrm{SO}_{4}-0.2 ; \mathrm{NH}_{4} \mathrm{Cl}-1.0 ; \mathrm{CaCl}_{2} \times 6 \mathrm{H}_{2} \mathrm{O}-0.06 ;$ $\mathrm{MgSO}_{4} \times 7 \mathrm{H}_{2} \mathrm{O}-0.1 ; \mathrm{C}_{3} \mathrm{H}_{5} \mathrm{O}_{3} \mathrm{Na}-2.0$; yeast extract - 1.0; $\mathrm{FeSO}_{4} \times 7 \mathrm{H}_{2} \mathrm{O}-0.004$; sodium citrate $\times 2 \mathrm{H}_{2} \mathrm{O}-0.3$.

Before bacterial seeding in the medium, $10 \mathrm{ml} / \mathrm{l}$ of sterile Mohr's salt solution $\left[\left(\mathrm{NH}_{4}\right)_{2} \mathrm{Fe}\left(\mathrm{SO}_{4}\right)_{2} \times 6 \mathrm{H}_{2} \mathrm{O}\right](10 \%)$, and $0.05 \mathrm{ml} / \mathrm{l}$ of sterile solution of $\mathrm{Na}_{2} \mathrm{~S} \times 9 \mathrm{H}_{2} \mathrm{O}(1 \%)$ were added. Sterile $10 \mathrm{~N}$ solution of $\mathrm{NaOH}(0.9 \mathrm{ml} / \mathrm{l})$ provided a medium of $\mathrm{pH} 7.2$. In each tube approximately $2 \mathrm{ml}$ of low temperature melting point paraffin $\left(+70^{\circ} \mathrm{C}\right)$ was poured over the surface of the medium and incubated at $+37^{\circ} \mathrm{C}$ for 10 days under anaerobic conditions. Cultures were deemed positive when a black FeS precipitate occurred in the bottom of the tube.

Kravtsov-Sorokin's liquid medium, to which $12 \mathrm{~g}$ of agar was added per litre, was used for surface cultures. Each positive culture was streaked on the poured Petri plates of Kravtsov-Sorokin's agar for obtaining isolated colonies. Mohr's salt in the agar medium for detecting colonies of the sulfate-reducing bacteria was added. As a result, FeS was formed by the bacterial cells that caused black coloured colonies. Plates were introduced into an anaerobic box with oxygen uptake generators (GENbox anaer, France) for anaerobiosis.

The black colonies obtained, both large and small, from each Petri plates were selected and suspended in sterile saline $(0.9 \%$ solution of $\mathrm{NaCl})$. They were seeded in the standard media: one with sulfate (concentration $3.5 \mathrm{mM}$ ), one without sulfate ions and another medium containing sulfur without sulfate ions, to be sure that the selected microorganisms belong to the sulfate-reducing bacteria.

Microscopy and morphological characteristics. Morphology of cells of the sulfate-reducing bacteria has been studied by using light microscope "MBR-1" $(\times 1350)$. Bacteria were observed by Gram staining from Kravtsov-Sorokin's liquid culture and also from the surface Kravtsov-Sorokin's agar culture. Flagella were examined using 
flagella stain reagent (Difco) from a 24-hr Kravtsov-Sorokin's agar slant in 160×16 mm tubes, which were incubated anaerobically. The bacteria were suspended in $0.2 \mathrm{ml}$ of sterile saline.

Tests on bacterial growth in the non-selective media. Additional tests on the growth of the obtained strains in different non-selective media (Meat Peptone Agar, Wort-Agar, Starch-and-Ammonia Agar, Giltay's, Baalsrud's, Kravtsov-Sorokin's) were performed [13]

Determination of bacterial sporulation. To determine the ability of the bacteria to sporulate, two types of these colonies were selected and suspended in the KravtsovSorokin's liquid medium. Thermoresistance was determined by heating $1 \mathrm{ml}$ of an 8-day culture in the liquid medium for $10 \mathrm{~min}$ at $+80^{\circ} \mathrm{C}$, then subculturing it in a similar medium incubated in anaerobiosis. To detect the bacterial spores the cells were additionally stained by Peshkov method.

Bacterial growth at various $\mathrm{pH}$. The influence of acidity $\mathrm{pH} 4.0,5.0,6.0,7.0,8.0$, $9.0,10.0)$ on the growth of the sulfate-reducing bacteria in the Kravtsov-Sorokin's liquid medium was established.

Growth at various temperatures. The growth of intestinal sulfate-reducing bacteria at various temperatures $\left(+4,+14,+20,+35,+45^{\circ} \mathrm{C}\right)$ in the Kravtsova-Sorokin's liquid medium after 6 days incubation was studied.

Bacterial biomass accumulation. Biomass accumulation of the various strains of sulfate-reducing bacteria in liquid medium by photometric method (nutritional medium was without Mohr's salt) has been examined [26].

Measuring of sulfate concentration. The sulfate ions concentration in the medium was determined by turbidymetric method after it had been precipitated by barium chloride. To stabilize the suspension glycerol was used [14].

Measuring of hydrogen sulfide concentration. Hydrogen sulfide concentration in the culture medium was determined by photometric method based on reaction of sulfide and $n$-aminodimethylaniline with methylene blue formation [25]. The concentration of hydrogen sulfide by calibration curve was established.

Measuring of lactate concentration. Determination of lactate concentration was carried out through dehydrogenation of lactate reaction by lactate dehydrogenase in the presence of NAD, with formation of pyruvate and NADH [27]. For the determination of lactate content, the following reagents were used: hydrazine-glycine buffer $\mathrm{pH} 9.0$ (glycine $-0.1 \mathrm{M}$ solution containing $0.1 \mathrm{M}$ hydrazine); $\mathrm{NAD}^{+}-0.03 \mathrm{M}$ solution, $\mathrm{pH} 6.0$; lactate dehydrogenase solution (protein content was about $2 \mathrm{mg} / \mathrm{ml}$ ). The samples of glycine and hydrazine were dissolved in a small amount of distilled water, the $\mathrm{pH}$ of the mixture was stabilized by $2 \mathrm{~N} \mathrm{NaOH}$ solution and it became 9.0 then diluted in the distilled water to $100 \mathrm{ml}$. Solutions of $\mathrm{NAD}^{+}$and lactate dehydrogenase were kept on ice. The tubes content was thoroughly mixed and then it was placed inside a thermostat at $+25^{\circ} \mathrm{C}$ for $60 \mathrm{~min}$. After the incubation, the samples were cooled and then the optical density of the samples was measured at $340 \mathrm{~nm}$. Taking into account all the dilutions, the quantity of the lactic acid was calculated.

Measuring of acetate ions concentration. The accumulation of acetate ions by the bacteria cultures during their growth in the medium was determined by titration [5].

Determination of other characteristics [3].

Catalase. This was tested on Kravtsov-Sorokin's surface agar cultures or in Kravtsov-Sorokin's liquid medium in the former case by placing one drop of a $10 \% \mathrm{H}_{2} \mathrm{O}_{2}$ solu-

ISSN 1996-4536 • Біологічні Студії / Studia Biologica • 2013 • Том 7/№3 • С. 115-132 
tion over the colonies and in liquid media by introducing five drops of a $10 \% \mathrm{H}_{2} \mathrm{O}_{2}$ solution in $1 \mathrm{ml}$ of a Kravtsov-Sorokin's liquid culture.

Indole production. This was tested using a 24-hr Kravtsov-Sorokin's liquid culture with nitric acid and isoamylic alcohol reagents (Salkowski's reaction).

Nitrate reduction. Sodium nitrate $(5 \%)$ was added to Kravtsov-Sorokin's liquid medium. Nitrites were tested with a napthylamine-sulfanilic acid reagent on a 24-hr culture.

Carbohydrate fermentation. Lactate, formate, propionate, fumarate, malate, methanol, citrate, ethanol, acetate, glycerol, oleate, stearate and benzoate were aseptically added to Kravtsov-Sorokin's liquid medium without electron donor and carbone source to obtain a final concentration of $1 \%$. Glucose and pyruvate fermentation was also checked in the Kravtsov-Sorokin's liquid medium. Acidity was analyzed by $\mathrm{pH}$ reaction and $\mathrm{pH}$ indicators.

Gas production. This was observed in Kravtsov-Sorokin's deep culture agar in $9 \times 180 \mathrm{~mm}$ tubes, inoculated with a Kravtsov-Sorokin's liquid culture.

Desulfoviridin production. This was examined using UV light on Kravtsov-Sorokin's agar surface cultures after treatment with a $1 \mathrm{~N} \mathrm{NaOH}$ solution.

Identification of sulfate-reducing bacteria. Identification of the sulfate-reducing bacteria by morphological, physiological and biochemical characteristics was conducted according to Bergey's Manual of Determinative Bacteriology [11].

Statistical analysis. Using the experimental data, the basic statistical parameters ( $\mathrm{M}$ - mean, $\mathrm{m}$ - standard error, $\mathrm{M} \pm \mathrm{m}$ ) have been calculated. For the estimation of the reliability between the statistical characteristics, Student's $t$-coefficient test was used. The difference was reliable when $\mathrm{P}>0.95$ [1]. Statistical processing of the results has been performed using packet Excel, Origin [12].

\section{RESULTS AND DISCUSSION}

Description of the obtained bacterial colonies and cell morphology. The results of the study showed that the isolated colonies on the selective solid nutrition medium with Mohr's salt were of identical shape (round), color (black), profile and structure; they differ only in size (large and small colonies). The size of the large colonies measured $2 \mathrm{~mm}$ in diameter with the small colonies measuring up to $1 \mathrm{~mm}$ in diameter. The bacterial colonies were black in colour, indicating the intense sulfate reduction. In Kravtsov-Sorokin's liquid medium all the strains showed a homogenous turbidity and a precipitation of iron from the sulfide.

Colonies were black and smooth when young and displayed a crater when older. After exposure to air, colonies decolorized quickly becoming yellow; at this stage the cells were dead. In Kravtsov-Sorokin's deep agar all the colonies were surrounded with a black halo of iron precipitation. Gas production was positive for all obtained strains. Desulfoviridin was produced by strains with large colonies but not by those with small colonies. All the strains were catalase positive and reduced nitrate. In addition, indol production was negative for all studied strains.

The ability of the strains to metabolize lactate, formate, propionate, pyruvate, fumarate, malate, methanol, citrate, ethanol, acetate, glycerol, glucose, oleate, stearate and benzoate was studied. The level of bacterial biomass accumulation in the medium with each of these substances was different. From this wide range of organic compounds studied bacteria grew only in the media with lactate, pyruvate, fumarate, malate, citrate, 
ethanol and glucose. Moreover, the bacteria grow well in medium with molecular hydrogen in the presence of carbon dioxide and acetate. Thus, studied strains are capable of hemolitoheterotrophic growth. In addition to organic acids with different carbon chain lengths and alcohol, the strains assimilated some amino acids.

Total number of the obtained SRB in the feces equaled $10^{5}$ colony-forming units per gram of feces. 157 obtained colonies of microorganisms were examined under the light microscope. The microscopic study showed that live bacterial preparations, made from 124 large bacterial colonies, contained active motile cells. The live bacterial preparations, taken from 33 small colonies, also contained motile cells. The cells of the large colonies were single vibrio-shaped and the cells of the small colonies displayed single short rods on fixed preparations. The bacterial cells of both these types of colonies were Gram-negative.

In previous research, the author has studied the ultrastructure of cells of the isolated bacteria under the electron microscope [17]. In the photos it was visible that the cells were rod-shaped or vibrio-shaped, surrounded by a cell wall and cytoplasmic membrane. In the cytoplasm the presence of nucleoid, ribosomes, and reserve substances was also observed. The results of electronic microscopic study helped to confirm the fact that two types of isolated colonies of SRB contain morphologically different cells. The large isolated colonies contain vibrio-like cells and the other small colonies contain short rods cells. The vibrio cells size is $0.6-0.8 \times 2.7-3.5 \mu \mathrm{m}$ and appear slightly curved with crescent forms. The short rods cells size is $0.5 \times 0.8-1.0 \mu \mathrm{m}$ and is similar to the coccobacilli forms. Thus, this is the morphology of the cells typical for sulfate-reducing bacteria.

The effect of oxygen on growth of the isolated bacterial strains. The cultivation of these microorganisms in anaerobic, microaerobic and aerobic conditions showed that aeration leads to cells death. However, the short contact of the SRB cells with oxygen does not cause their instant death. This may be due to the high activity of antioxidant enzymes, catalase and superoxide dismutase [2, 23]. The obtained strains are obligate (strict) anaerobes.

The effect of $\mathrm{pH}$ on growth of the selected bacterial strains. It was established that the most intensive growth of all the bacterial strains and hydrogen sulfide accumulation were observed at $\mathrm{pH}$ 7.0-8.0. The decreasing and increasing acidity of the medium was accompanied by the decrease of the bacteria growth rate and hydrogen sulfide production. Similar results were obtained by Furutani et al which established that at low $\mathrm{pH}$ the process of dissimilatory sulfate reduction was significantly slowed [7]. Increasing of the $\mathrm{pH}$ medium to 9.0-10.0 also caused growth inhibition of the studied bacteria.

Growth of the bacterial strains in various media. To determine which subgroups the identified bacteria belong to, the selected suspended bacterial colonies (large and small) were seeded in media with and without sulfates and in the medium with elemental sulfur without sulfates. All of these media contained sodium lactate as a carbon source.

The results shown that the studied bacteria grow well only in the medium with sulfate ions and sodium lactate (Table 1). Due to the results obtained, the isolated strains belong to the group of sulfate-reducing bacteria.

The studied bacterial strains do not grow in the medium without sulfates and also do not grow in the medium with molecular sulfur and lactate without sulfates. Therefore they are unable to use sulfur as an electron acceptor. This was helped by confirming the absence among isolated bacteria of the Desulfurella and Desulfuromonas genera. Thus, the obtained bacterial strains do not belong to the fourth subgroup of sulfur-reducing bacteria, since the bacteria do not use the sulfur.

ISSN 1996-4536 • Біологічні Студії / Studia Biologica • 2013 • Том 7/№3 • С. 115-132 
Table 1. Growth of large and small bacterial colonies in the medium supplemented with sulfates, without sulfates, and containing sulfur without sulfate ions

Таблиця 1. Ріст великих і малих бактеріальних колоній у середовищі зі сульфатами, без сульфатів, а також у середовищі зі Сульфуром без наявності сульфат-іонів

\begin{tabular}{c|c|c|c}
\hline \multirow{2}{*}{ Strains of SRB } & \multicolumn{3}{|c}{ Growth in the Kravtsov-Sorokin's medium } \\
\cline { 2 - 4 } & $\begin{array}{c}\text { with } \\
\text { sulfate ions }\end{array}$ & $\begin{array}{c}\text { without } \\
\text { sulfate ions }\end{array}$ & $\begin{array}{c}\text { with sulfur } \\
\text { without sulfate ions }\end{array}$ \\
\hline SRB Vib-1 & + & - & - \\
\hline SRB Vib-2 & + & - & - \\
\hline SRB Vib-3 & + & - & - \\
\hline SRB Vib-4 & + & - & - \\
\hline SRB Vib-5 & + & - & - \\
\hline SRB Vib-6 & + & - & - \\
\hline SRB Vib-7 & + & - & - \\
\hline SRB Vib-8 & + & - & - \\
\hline SRB Vib-9 & + & - & - \\
\hline SRB Vib-10 & + & - & - \\
\hline SRB Rod-1 & + & - & - \\
\hline SRB Rod-2 & + & - & - \\
\hline SRB Rod-3 & + & - & - \\
\hline SRB Rod-4 & + & - & - \\
\hline SRB Rod-5 & + & - & - \\
\hline SRB Rod-6 & + & - & - \\
\hline SRB Rod-7 & + & - & - \\
\hline SRB Rod-8 & + & - & - \\
\hline SRB Rod-9 & + & - & - \\
\hline SRB Rod-10 & + & - & - \\
\hline desulfuricans & + & - & - \\
\hline
\end{tabular}

Notes: "+" - active bacterial growth; "-" - no bacterial growth

Примітки: “+” - активний бактеріальний ріст; “-” - росту бактерій нема

Moreover, the additional tests on the growth of the obtained strains under anaerobic conditions in different non-selective media (Meat Peptone Agar, Wort-Agar, Starchand-Ammonia Agar, Giltay's, Baalsrud's, Kravtsov-Sorokin's) were performed (Table 2).

This research has helped to check the purity of isolated cultures and further confirm that the selected strains are the sulfate-reducing bacteria since bacterial growth was only in the Kravtsov-Sorokin's medium. 
Table 2. Growth of large and small colonies of the sulfate-reducing bacteria in various media

Таблиця 2. Ріст великих і малих колоній сульфатвідновлювальних бактерій на різних середовищах

\begin{tabular}{c|c|c|c|c|c|c}
\hline \multirow{2}{*}{ Strains of SRB } & \multicolumn{7}{|c}{ Media } \\
\cline { 2 - 7 } & $\begin{array}{c}\text { Meat Peptone } \\
\text { Agar }\end{array}$ & Wort-Agar & $\begin{array}{c}\text { Starch-and- } \\
\text { Ammonia Agar }\end{array}$ & Giltay's & Baalsrud's & $\begin{array}{c}\text { Kravtsov- } \\
\text { Sorokin's }\end{array}$ \\
\hline SRB Vib-1 & - & - & - & - & - & + \\
\hline SRB Vib-2 & - & - & - & - & - & + \\
\hline SRB Vib-3 & - & - & - & - & - & + \\
\hline SRB Vib-4 & - & - & - & - & - & + \\
\hline SRB Vib-5 & - & - & - & - & - & + \\
\hline SRB Vib-6 & - & - & - & - & - & + \\
\hline SRB Vib-7 & - & - & - & - & - & + \\
\hline SRB Vib-8 & - & - & - & - & - & + \\
\hline SRB Vib-9 & - & - & - & - & - & + \\
\hline SRB Vib-10 & - & - & - & - & - & + \\
\hline SRB Rod-1 & - & - & - & - & - & + \\
\hline SRB Rod-2 & - & - & - & - & - & + \\
\hline SRB Rod-3 & - & - & - & - & - & + \\
\hline SRB Rod-4 & - & - & - & - & - & + \\
\hline SRB Rod-5 & - & - & - & - & - & + \\
\hline SRB Rod-6 & - & - & - & - & - & + \\
\hline SRB Rod-7 & - & - & - & - & - & + \\
\hline SRB Rod-8 & - & - & - & - & - & + \\
\hline SRB Rod-9 & - & - & - & - & - & + \\
\hline SRB Rod-10 & - & - & - & - & - & + \\
\hline D. desulfuricans & - & - & - & - & - & + \\
\hline Strain IMV K-6 & - & - & - & - & - & + \\
\hline Notes: & - & - & - & - & - & + \\
\hline
\end{tabular}

Notes: "+" - active bacterial growth; "-" - no bacterial growth

Примітки: "+” - активний бактеріальний ріст; “-” - росту бактерій нема

Detection of the bacterial spores. Growth of the selected bacterial colonies in the medium after their heating at $+80^{\circ} \mathrm{C}$ for $10 \mathrm{~min}$, allowed for no further growth. This was further supported by the fact that the selected bacteria colonies cells do not form spores (Table 3).

Staining bacterial cells of isolated colonies by the Peshkov method has helped to confirm that none of the colonies contain sporeforming bacteria. This has helped to reach the conclusion that the isolated bacteria can not form spores. Therefore, among the isolated cultures there are no representatives of the Desulfotomaculum genus (the first subgroup of the sulfate-reducing bacteria according to Bergey's Manual of Determinative Bacteriology). 
Table 3. Ability to sporulate in large and small colonies of the sulfate-reducing bacteria

Таблиця 3. Здатність великих і малих колоній сульфатвідновлювальних бактерій утворювати спори

\begin{tabular}{c|c|c|c}
\hline \multirow{2}{*}{ Strains of SRB } & $\begin{array}{c}\text { Presence of bacterial spores } \\
\text { (stained by Peshkov) }\end{array}$ & $\begin{array}{c}\text { Before incubation } \\
\text { at }+80^{\circ} \mathrm{C}\end{array}$ & $\begin{array}{c}\text { After incubation } \\
\text { at +80 } \mathrm{C}\end{array}$ \\
\cline { 3 - 4 } & - & + & - \\
\hline SRB Vib-1 & - & + & - \\
\hline SRB Vib-2 & - & + & - \\
\hline SRB Vib-3 & - & + & - \\
\hline SRB Vib-4 & - & + & - \\
\hline SRB Vib-5 & - & + & - \\
\hline SRB Vib-6 & - & + & - \\
\hline SRB Vib-7 & - & + & - \\
\hline SRB Vib-8 & - & + & - \\
\hline SRB Vib-9 & - & + & - \\
\hline SRB Vib-10 & - & + & - \\
\hline SRB Rod-1 & - & + & - \\
\hline SRB Rod-2 & - & + & - \\
\hline SRB Rod-3 & - & + & - \\
\hline SRB Rod-4 & - & + & - \\
\hline SRB Rod-5 & - & + & - \\
\hline SRB Rod-6 & - & + & - \\
\hline SRB Rod-7 & - & + & - \\
\hline SRB Rod-8 & - & + & - \\
\hline SRB Rod-9 & - & + & - \\
\hline SRB Rod-10 & - & + & - \\
\hline desulfuricans & - & + & - \\
\hline Noin IMV K-6 & - & + & - \\
\hline
\end{tabular}

Notes: "+" - active bacterial growth; "-" - no bacterial growth

Примітки: “+” - активний бактеріальний ріст; “-” - росту бактерій нема

The effect of temperature on growth of the selected bacterial strains. The highest biomass of all the strains of bacteria was observed at $+35^{\circ} \mathrm{C}$ temperature on the sixth day of bacterial growth (Fig. 1). Under these conditions, in comparison with the other vibrio-shaped strains, the highest biomass was accumulated by SRB Vib-1, SRB Vib-3 and SRB Vib-8 strains (Fig. 1A).

Compared to the other rod-shaped strains, the highest biomass was accumulated at $+35^{\circ} \mathrm{C}$ temperature by SRB Rod-3, SRB Rod-4, SRB Rod- 9 and SRB Rod-10 strains (Fig. 1B). 

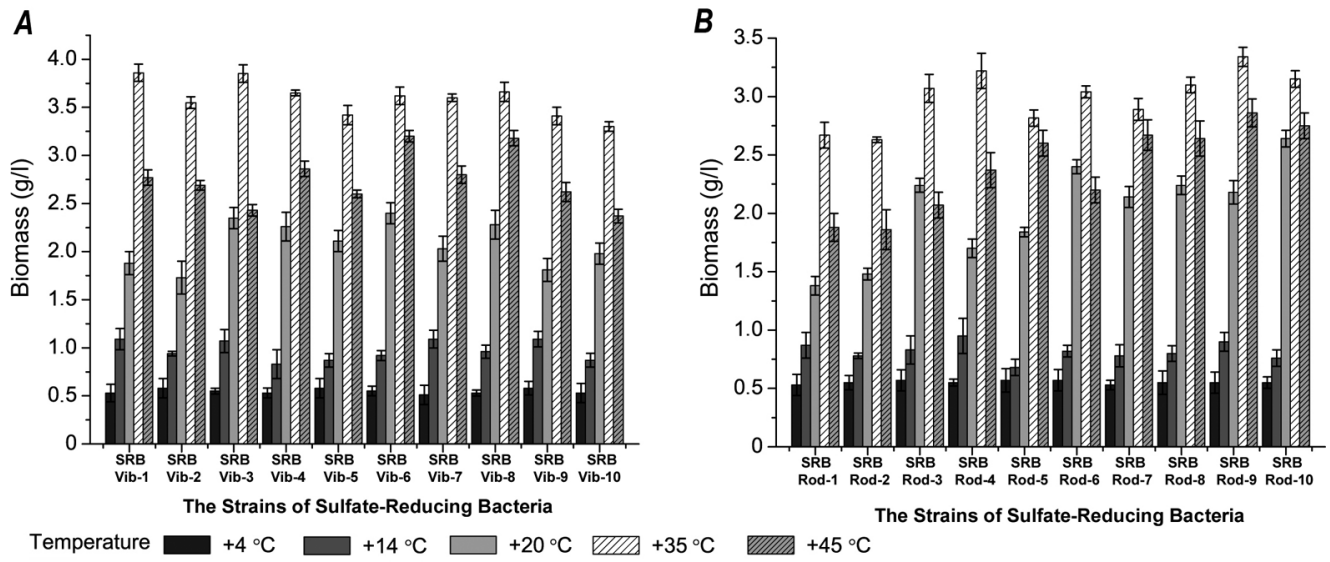

Fig. 1. The effect of temperature on growth of various strains of the sulfate-reducing bacteria on the sixth day of cultivation: $A$ - vibrio-shaped strains; $B$ - short rods-shaped strains

Рис. 1. Вплив температури на ріст різних штамів сульфатвідновлювальних бактерій на шостий день культивування: $A$ - вібріоподібні штами; $B$ - паличкоподібні штами

At $+20^{\circ} \mathrm{C}$ and $+45^{\circ} \mathrm{C}$ temperature less intensive growth of bacterial strains was observed. The least biomass was accumulated by the isolates at $+14^{\circ} \mathrm{C}$ temperature. Bacterial growth at $+4^{\circ} \mathrm{C}$ temperature was not observed. Thus, $+35^{\circ} \mathrm{C}$ temperature was the optimum temperature for growth of the selected strains of bacteria.

Bacterial growth and dissimilatory sulfate reduction by the selected bacterial strains. Bacterial growth and sulfate reduction processes performed by different strains of SRB were studied. The results of the study showed that all the isolates were actively growing, using sulfate as an electron acceptor and accumulating hydrogen sulfide in the medium. These bacterial strains use lactate as the electron donor which is incompletely oxidized by the bacteria, to acetate (Figs. 2-3).

Different growth rates of various strains of SRB in the modified Kravtsov-Sorokin's medium have been studied. The biomass accumulated by the studied vibrio-shaped bacterial strains was highest when compare with the rod-shaped strains (Fig. 2).

The studied SRB use sulfate and lactate with varying intensity of hydrogen sulfide and acetate producing. The intense growth of these bacteria depended on the use of sulfate, lactate, and the accumulation of hydrogen sulphide and acetate. A strong reverse negative correlation between these processes was established.

Having used all the sulfate and lactate in the medium, the bacteria stopped growing and the stationary growth phase began. The limiting factors of the growth of these bacteria were hydrogen sulfide and acetate, produced by the bacteria in the processes of dissimilatory sulfate reduction and lactate oxidation respectively.

In comparison to the vibrio-shaped strains, the rod-shaped strains of the SRB reduced sulfate, oxidized lactate, and produced hydrogen sulfide in the medium less intensively (Fig. 3). Such usage of acceptor and donor electrons by the rod-shaped bacteria had influence on their growth in the medium. This growth was less intense in comparison to the vibrio-shaped strains.

Among all the isolated bacteria the highest biomass (up to 3.89 gram per liter) was accumulated by the SRB Vib-7 strain on the sixth day of cultivation. The lowest biomass (up to 3.41 gram per liter) among vibrios strains was accumulated by the SRB Vib-10 

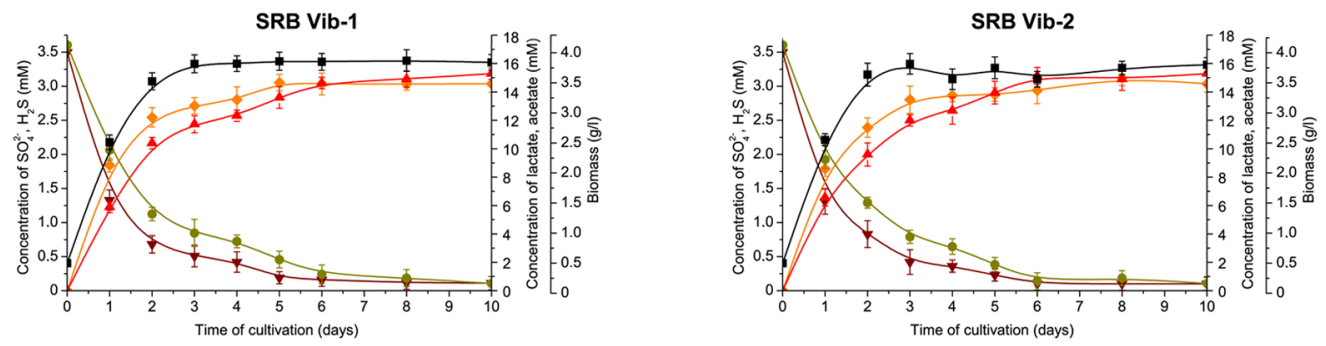

SRB Vib-3
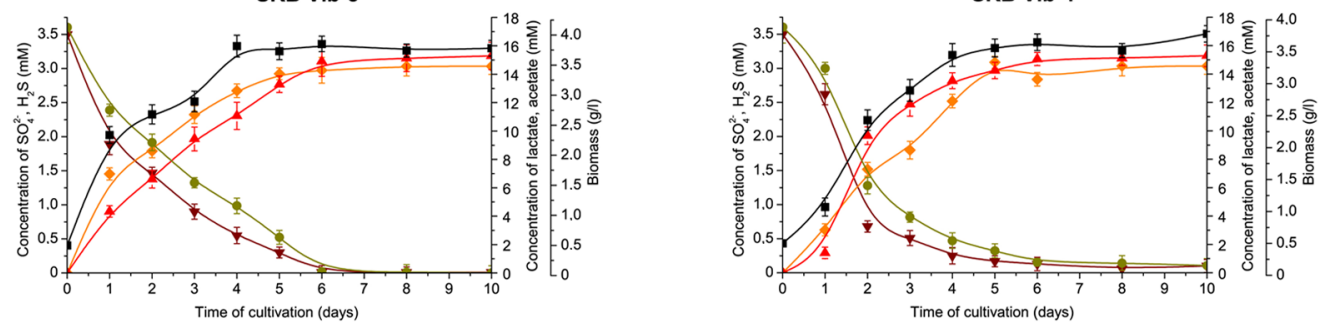

SRB Vib-5
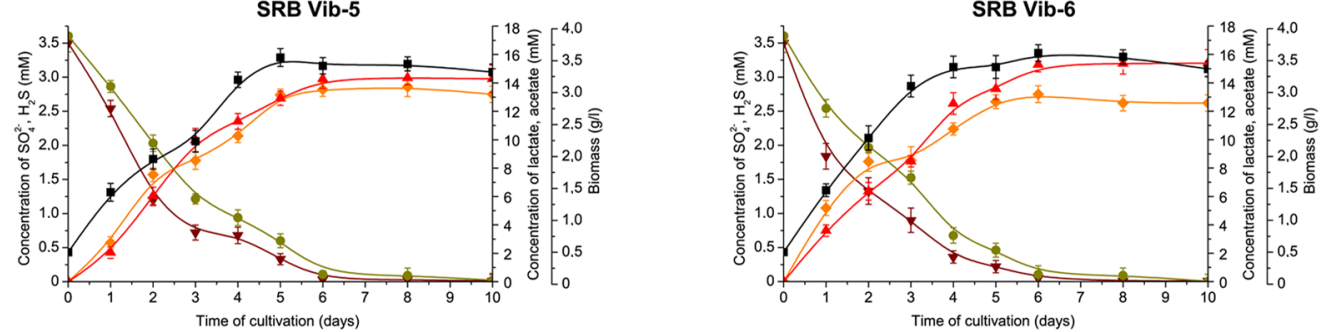

SRB Vib-7
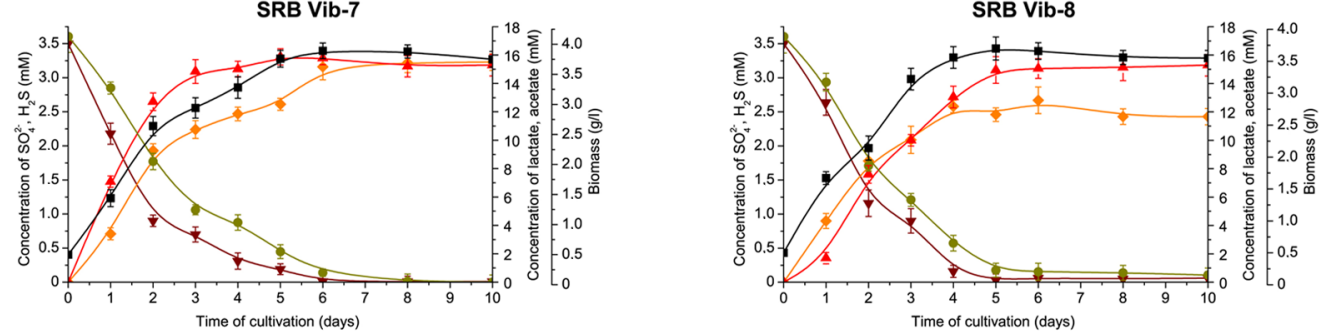

SRB Vib-9
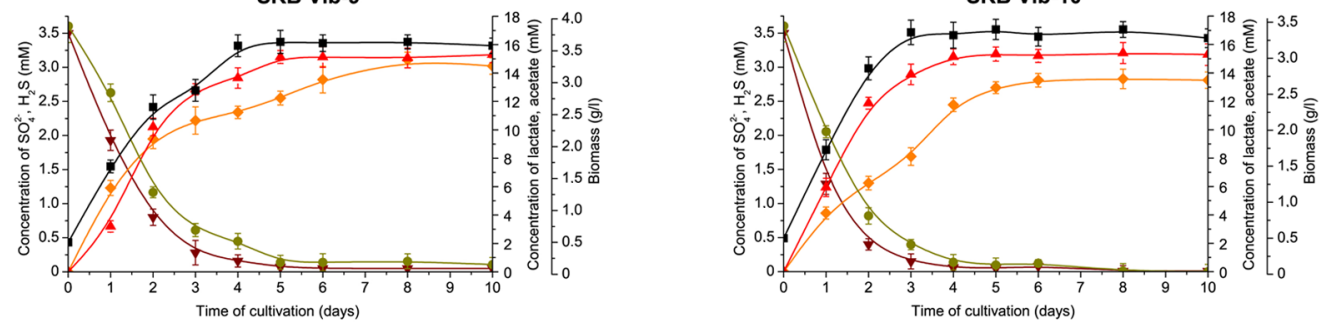

Fig. 2. Growth of various SRB vibrio-shaped strains, sulfate- and lactate usage, production of hydrogen sulfide and acetate: $-\boldsymbol{-}-$ biomass; $-\boldsymbol{\nabla}$ - sulfate; $-\downarrow-$ sulfide; $-\bullet-$ lactate; $-\boldsymbol{\Delta}$ - acetate

Рис. 2. Ріст різних вібріоподібних штамів СВБ, використання ними сульфату і лактату, а також утворен-

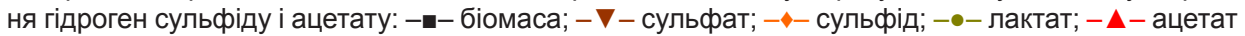




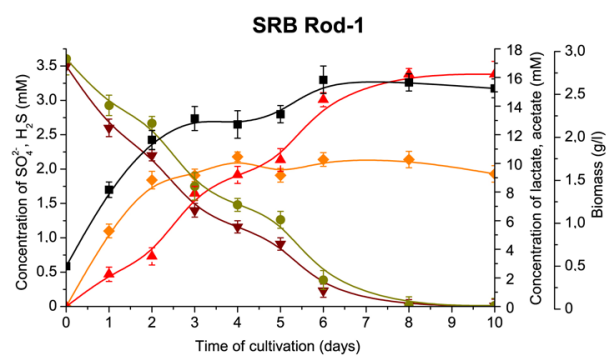

SRB Rod-3

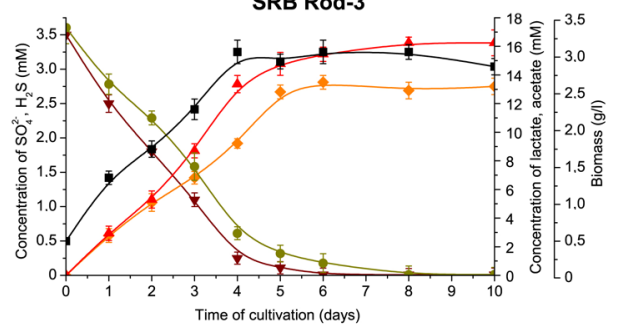

SRB Rod-5

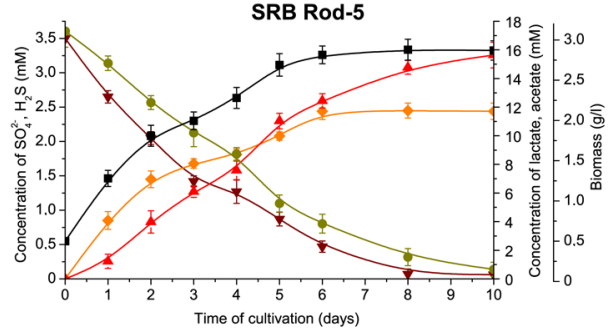

SRB Rod-7

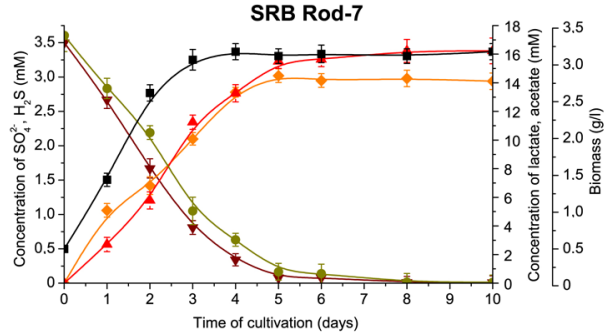

SRB Rod-9

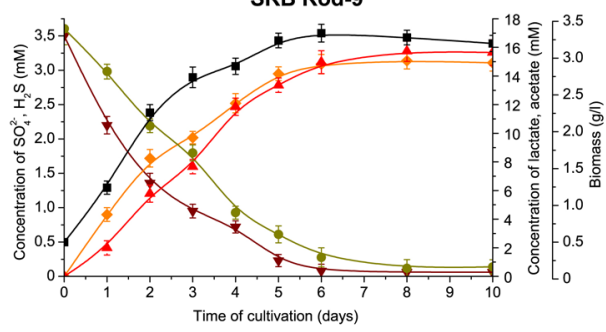

SRB Rod-2

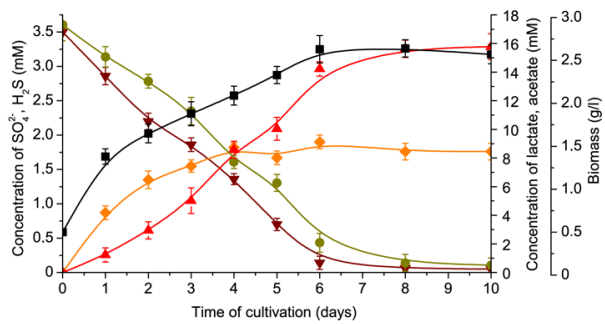

SRB Rod-4

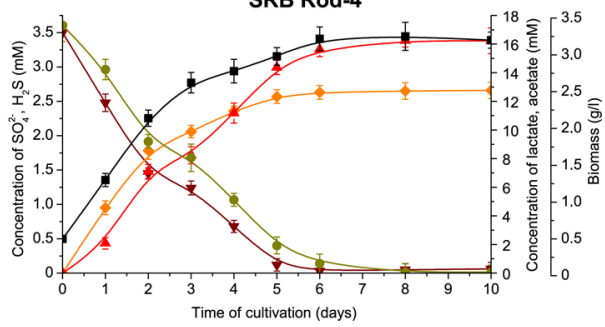

SRB Rod-6

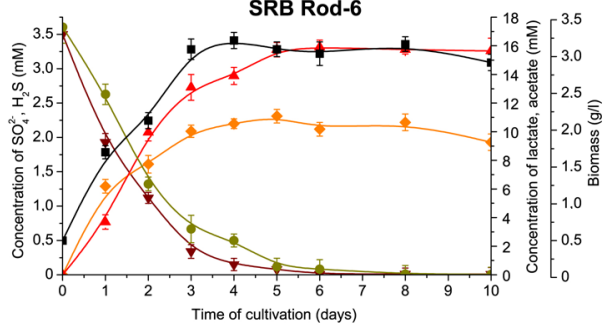

SRB Rod-8

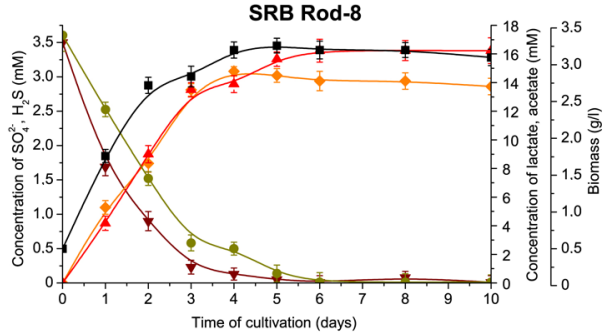

SRB Rod-10

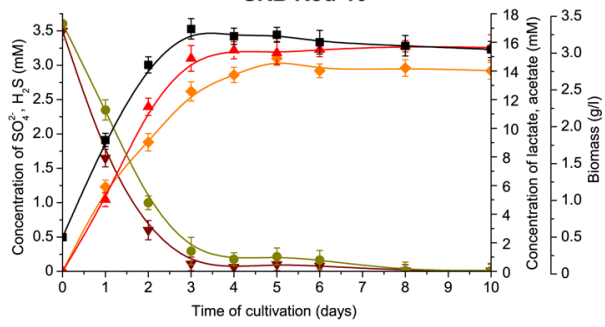

Fig. 3. Growth of various SRB rod-shaped strains, sulfate- and lactate usage, production of hydrogen sulfide and acetate: - - - biomass; $-\boldsymbol{\nabla}$ - sulfate; $-\downarrow-$ sulfide; $-\bullet$ - lactate; $-\mathbf{\Delta}$ - acetate

Рис. 3. Ріст різних паличкоподібних штамів СВБ, використання ними сульфату і лактату, а також утворен-

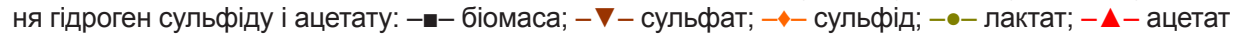


strain on the eighth day of cultivation. Among the rod-shaped strains the highest biomass (up to 3.34 gram per liter) was accumulated by the SRB Rod-9 strain on the sixth day of cultivation, in comparison to the other rod-shaped strains, while the SRB Rod-2 strain accumulated the lowest biomass (up to 2.64 gram per liter) on the eighth day of cultivation.

The highest concentration of hydrogen sulfide (up to $3.23 \mathrm{mM}$ ) among the vibrioshaped strains was produced by the bacterial SRB Vib-7 strain on the eighth day of cultivation; while the bacteria used about $99 \%$ of the sulfate in the medium, compared to the initial concentration of the sulfate. The SRB Vib-8 strain produced hydrogen sulfide in the lowest concentration (up to $2.67 \mathrm{mM}$ ) on the sixth day of cultivation, compared to the vibrio-shaped strains; under these conditions, about $98 \%$ of sulfate ions were used in the medium compared to its initial concentration.

Among the rod-shaped strains, the highest concentration of hydrogen sulfide (up to $3.14 \mathrm{mM}$ ) was produced by the SRB Rod-9 strain on the eighth day of cultivation. At this time, the strain used about $98 \%$ of the sulfate in the medium. The bacterial SRB Rod-2 strains produced the lowest concentration of hydrogen sulfide (up to $1.91 \mathrm{mM}$ ) on the sixth day of cultivation; they used about $97 \%$ of the sulfate in the medium, compared to its initial concentration.

Among all the vibrio-shaped strains, the bacterial SRB Vib-7 strain produced the highest concentration of acetate ions (up to $15.87 \mathrm{mM}$ ) on the fifth day of cultivation; while the bacteria used about $97 \%$ of lactate in the medium, compared to its initial concentration. The SRB Vib-5 strain produced the lowest concentration (up to $14.36 \mathrm{mM}$ ) of acetate ions on the eighth day of cultivation, compared to the vibrio-shaped strains; under these conditions, the strain used about $98 \%$ of lactate in the medium, compared to its initial concentration. Among the rod-shaped strains the highest concentration of acetate ions (up to $16.24 \mathrm{mM}$ ) produced by the SRB Rod-4 strain on the eighth day of cultivation; at this time the strain used about $99 \%$ of lactate in the medium. The bacterial SRB Rod-5 strains produced the lowest concentration of acetate ions (up to $15.64 \mathrm{mM}$ ) on the tenth day of cultivation; they used about $98 \%$ of lactate in the medium compared to its initial concentration.

Therefore, the studied bacteria actively reduced sulfates and produced hydrogen sulfide due to incomplete lactate oxidation by the strains accumulating acetate ions in the medium. This data has helped to establish that the obtained bacterial strains do not belong to the third subgroup, containing asporogenous sulfate-reducing bacteria that completely oxidize the organic substrates to $\mathrm{CO}_{2}$.

All isolated strains of bacteria actively produced acetate and lactate oxidation was incomplete. Thus, the isolated strains belong to the second subgroup that contains asporogenous sulfate-reducing bacteria; they oxidize organic compounds incompletely to acetate.

The next task of the study was to establish to which genera the selected bacteria strains belong. The subgroup includes Desulfobulbus, Desulfomicrobium, Desulfomonas, Desulfovibrio and Thermodesulfobacterium genera. For the identification the table of Bergey's Manual of Determinative Bacteriology was used (Table 4) [11].

Growth of all the isolated strains in the modified Kravtsov-Sorokin's medium with sulfates and propionate (without lactate) was investigated. The results of this study showed that none of the bacterial cultures grow in this medium with propionate, which eliminates the possibility of belonging to the Desulfobulbus genus. 
Table 4. Differentiating features of the sulfate-reducing bacteria genera of second subgroup [11]

Таблиця 4. Розподіл ознак родів сульфатвідновлювальних бактерій другої підгрупи [11]

\begin{tabular}{|c|c|c|c|c|c|}
\hline \multirow[b]{2}{*}{ Features } & \multicolumn{5}{|c|}{ Bacterial genera of the second subgroup } \\
\hline & $\begin{array}{l}\text { Desulfo- } \\
\text { bulbus }\end{array}$ & $\begin{array}{l}\text { Desulfo- } \\
\text { microbium }\end{array}$ & $\begin{array}{l}\text { Desulfo- } \\
\text { monas }\end{array}$ & $\begin{array}{l}\text { Desulfo- } \\
\text { vibrio }\end{array}$ & $\begin{array}{c}\text { Thermo- } \\
\text { desulfo- } \\
\text { bacterium }\end{array}$ \\
\hline Spiral or vibrio-shaped cells & - & - & - & + & - \\
\hline Oval or rod-shaped cells & + & + & + & - & + \\
\hline Movement with the polar flagella & $+1-$ & + & - & $+1-$ & $+1-$ \\
\hline \multicolumn{6}{|l|}{ Optimal temperature range } \\
\hline$+25 \ldots+40^{\circ} \mathrm{C}$ & + & + & + & + & - \\
\hline$+65 \ldots+70^{\circ} \mathrm{C}$ & - & - & - & - & + \\
\hline \multicolumn{6}{|l|}{$\begin{array}{l}\text { Ability of bacteria to grow in the presence } \\
\text { of sulfate }\end{array}$} \\
\hline $\mathrm{H}_{2}+\mathrm{CO}_{2}+$ acetate as a carbon source & + & + & + & + & + \\
\hline lactate & + & + & + & + & + \\
\hline propionate & + & - & - & - & - \\
\hline Desulfoviridin & - & - & + & + & - \\
\hline
\end{tabular}

Notes: "+" - the presence of the feature; "-" - the absence of the feature

Примітки: “+” - наявність ознаки; “-” - ознаки нема

It was established that $+35^{\circ} \mathrm{C}$ is the optimum temperature for growth of the studied bacterial strains. Increase of temperature to $+45^{\circ} \mathrm{C}$ caused a decrease in the intensity of the bacterial growth. It has helped to establish that none of the isolated strains belong to the Thermodesulfobacterium genus which grow at high temperatures $\left(+65 \ldots+70^{\circ} \mathrm{C}\right)$.

The isolated strains also can not belong to the Desulfomonas genus because the studies have shown that all the isolated bacteria are motile due to a single polar flagellum.

The growth of the obtained strains in the Kravtsov-Sorokin's medium (without lactate) with different carbon sources was studied. The studies have shown that bacteria grew in the medium with acetate, pyruvate, ethanol, malate, and fumarate.

Taking into consideration all the obtained results, investigation of bacterial growth in different media; ability to form spores; temperature and acidic optima; the ability to reduce sulfate to hydrogen sulfide; production of acetate as a result of utilization of lactate; morphology; growth in the medium with lactate; acetate and other carbon sources, the isolated bacteria may therefore be identified as Desulfovibrio sp. and Desulfomicrobium sp.

On the basis of the results of the studies and the established morphological, physiological and biochemical characteristics (according to the Bergey's Manual of Determinative Bacteriology), studied isolated bacterial strains are as follows:

- vibrio-shaped (SRB Vib-1, SRB Vib-2, SRB Vib-3, SRB Vib-4, SRB Vib-5, SRB Vib-6, SRB Vib-7, SRB Vib-8, SRB Vib-9, SRB Vib-10) are identified as Desulfovibrio sp.;

- rod-shaped (SRB Rod-1, SRB Rod-2, SRB Rod-3, SRB Rod-4, SRB Rod-5, SRB Rod-6, SRB Rod-7, SRB Rod-8, SRB Rod-9, SRB Rod-10) are identified as Desulfomicrobium sp. 
According to the Bergey's manual of Systematic Bacteriology (2005), the obtained genera belong to Class IV. Deltaproteobacteria; Order II. Desulfovibrionales; Family I. Desulfovibrionaceae (Genus I. Desulfovibrio) and Family II. Desulfomicrobiaceae (Genus I. Desulfomicrobium) [4].

\section{CONCLUSIONS}

Twenty pure cultures of the sulfate-reducing bacteria of human intestine were obtained. The results of studies of their morphological, physiological and biochemical characteristics showed that the obtained bacterial strains belong to the Desulfovibrio and Desulfomicrobium genera according to the Bergey's Manual of Determinative Bacteriology. All the obtained bacterial cultures extensively used sulfate, lactate and produced hydrogen sulfide as well as acetate during growth in the modified KravtsovSorokin's medium. The Desulfovibrio sp. strain Vib-7 produced the highest concentration (up to $3.23 \mathrm{mM}$ ) of hydrogen sulfide on the eighth day of cultivation among the studied Desulfovibrio sp. strains; while the bacteria used about $99 \%$ of the sulfate in the medium, compared to the initial concentration of the sulfate. Among all the studied Desulfovibrio sp. strains, the Desulfovibrio sp. strain Vib-7 produced the highest concentration of acetate ions (up to $15.87 \mathrm{mM}$ ) on the fifth day of cultivation. Among the studied Desulfomicrobium sp. strains the highest concentration of hydrogen sulfide (up to $3.14 \mathrm{mM}$ ) produced by the Desulfomicrobium sp. Rod-9 strain on the eighth day of cultivation; the strain used about $98 \%$ of sulfate in the medium. The Desulfomicrobium $\mathrm{sp}$. strain Rod-4 produced the highest concentration of acetate ions (up to $16.24 \mathrm{mM}$ ) among all the studied Desulfomicrobium sp. strains.

The optimum growth of the studied bacteria at $+35^{\circ} \mathrm{C}$ temperature suggests that the isolated cultures can actively develop in the human intestine and extensively produce hydrogen sulfide and acetate in its lumen. The presence and activity of these microorganisms in the human intestine may be considerably responsible for the development of very serious pathological conditions of the human intestine, causing disease.

\section{ACKNOWLEDGEMENTS}

The author expresses his gratitude to Lucy Mclennan and Robyn Cochrane from Forensic Biology, Immunology and Microbiology at University of Strathclyde (Scotland, United Kingdom) for their assistance and reading the manuscript.

1. Bailey N.T.J. Statistical Methods in Biology. Third edition. Cambridge University Press, 1995. $255 \mathrm{p}$.

2. Barton L.L., Hamilton W.A. Sulphate-reducing Bacteria. Environmental and Engineered. Cambridge University Press, 2007. 553 p.

3. Beerens $H$., Romond C. Sulfate-reducing anaerobic bacteria in human feces. The American Journ. of Clin. Nutr, 1977; 30: 1770-1776.

4. Brenner D.J., Krieg N.R., Staley J.T., Garrity G.M. Bergey's manual of Systematic Bacteriology. Vol. Two: The Proteobacteria, Part C: The Alpha-, Beta-, Delta-, and Epsilonproteobacteria. Second Edition. Printed in the United States of America, 2005. 1388 p.

5. Campbell M.K., Farrell S.O. Biochemistry. Sixth Edition. Publisher: Cengage Learning, 2008. $800 \mathrm{p}$. 
6. Cummings J.H., Macfarlane G.T., Macfarlane S. Intestinal Bacteria and Ulcerative Colitis. Curr. Issues Intest. Microbiol, 2003; 4: 9-20.

7. Furutani A., Schindler D.W. Effects of lake acidification on rates of organic matter decomposition. Limnol. Oceanogr, 1984; 29: 687-694.

8. Gibson G.R., Cummings J.H., Macfarlane G.T. Growth and activities of sulphate-reducing bacteria in gut contents of health subjects and patients with ulcerative colitis. FEMS Microbiol. Ecol, 1991; 86: 103-112.

9. Gibson G.R., Macfarlane G.T., Cummings J.H. Sulphate-reducing bacteria and hydrogen metabolism in the human large intestine. Gut, 1993; 34: 437-439.

10. Gibson G.R., Macfarlane S., Macfarlane G.T. Metabolic interactions involving sulfate-reducing and methanogenic bacteria in the human large intestine. FEMS Microbiol. Ecol, 1993; 12: 117-125.

11. Holt J.G., Krieg N.R., Sneath P.H. et al. Bergey's Manual of Determinative Bacteriology. Ninth Edition. Moscow: Mir, 1997; 1. 426 p.

12. Isakova O.P., Tarasevych Yu.Yu., Yuzjuk Yu.l. Processing and visualization of data with the physical experiments by usage Origin package. Moscow: Book House "LIBKOM", 2009; $136 \mathrm{p}$.

13. Karavayko G.I., Kuznetsov S.I., Golomzik A.I. A role of microorganisms in a leaching of metals from ores. Moscow: Science, 1972. $248 \mathrm{p}$.

14. Kolmert A., Wikstrom P., Hallberg K.B. A fast and simple turbidimetric method for the determination of sulfate in sulfate-reducing bacterial cultures. Journ. of Microbiol. Methods, 2000; 41: 179-184.

15. Kushkevych I.V. Sulfate-reducing bacteria of the human intestine. I. Dissimilatory sulfate reduction. Sci Int Jour Biological Studies/Studia Biologica, 2012; 6(1): 149-180.

16. Kushkevych I.V. Sulfate-reducing bacteria of the human intestine. II. The role in the diseases development. Sci Int Jour Biological Studies/Studia Biologica, 2012; 6(2): 221-250.

17. Kushkevych I.V., Moroz O.M. Growth of various strains of sulfate-reducing bacteria of human large intestine. Sci Int Jour Biological Studies/Studia Biologica, 2012; 6(3): 115-124.

18. Langendijk P.S., Kulik E.M., Sandmeier H. et al. Isolation of Desulfomicrobium orale sp. nov. and Desulfovibrio strain NY682, oral sulfate-reducing bacteria involved in human periodontal disease. J. Syst. Evol. Microbiol, 2001; 51(3): 1035-1044.

19. Loubinoux J., Bronowicji J.P., Pereira I.A. et al. Sulphate-reducing bacteria in human feces and their association with inflammatory diseases. FEMS Microbiol. Ecol, 2002; 40: 107-112.

20. Loubinoux J., Mory F., Pereira I.A., Le Faou A.E. Bacteremia caused by a strain of Desulfovibrio related to the provisionally named Desulfovibrio fairfieldensis. J. Clin. Microbiol, 2000; 38: 931-934.

21. Macfarlane S., Dillon J.F. Microbial biofilms in the human gastrointestinal tract. J. Appl. Microbiol, 2007; 102: 1187-1196.

22. Pitcher M.C., Cummings J.H. Hydrogen sulphide: a bacterial toxin in ulcerative colitis? Gut, 1996; 39: 1-4.

23. Postgate J.R. The sulfate-reducing bacteria. Second edition. Cambridge Univ. Press, 1984. $199 \mathrm{p}$.

24. Rowan F.E., Docherty N.G., Coffey J.C., O'Connell P.R. Sulphate-reducing bacteria and hydrogen sulphide in the aetiology of ulcerative colitis. British Journal of Surgery, 2009; 96 : 151-158.

25. Sugiyama M. Reagent composition for measuring hydrogen sulfide and method for measuring hydrogen / U.S. Pat. 6340596 B1 USA, Int. Cl. G 01 N 33/00, 2002.

26. Sutton $S$. Measurement of Microbial Cells by Optical Density. Journal of Validation Technology, 2011; 17(1): 46-49.

ISSN 1996-4536 • Біологічні Студії / Studia Biologica • 2013 • Том 7/№3 • С. 115-132 
27. Vlizlo V.V., Fedoruk R.S., Makar I.A. et al. Physiological and biochemical methods of researches in biology, stockbreeding and veterinary medicine. Handbook: Institute of Animal Biology. Third Edition: revised and enlarged. Lviv, 2004. 402 p.

28. Zinkevich V.V., Beech I.B. Screening of sulfate-reducing bacteria in colonoscopy samples from healthy and colitic human gut mucosa. FEMS Microbiol. Ecol, 2000; 34: 147-155.

\section{ІДЕНТИФІКАЦІЯ ШТАМІВ СУЛЬФАТВІДНОВЛЮВАЛЬНИХ БАКТЕРІЙ ТОВСТОГО КИШЕЧНИКА ЛЮДИНИ}

\section{I. В. Кушкевич}

Університет ветеринарних та фрармацевтичних наук Брно 1/3, Palackeho, CZ-61242 Брно, Чеська Республіка e-mail: ivan.kushkevych@gmail.com

Ізольовано сульфатвідновлювальні бактерії кишечника людини. Ці бактерії ідентифіковано як Desulfovibrio sp. і Desulfomicrobium sp. за їх морфологічними, фрізіологічними і біохімічними характеристиками відповідно до Визначника бактерій Берджі. Досліджено ріст цих бактерій за різних умов, зокрема на різних середовищах, за впливу кисню, pH і температури. Вивчено ріст бактерій у модифікованому середовищі Кравцова-Сорокіна і процеси дисиміляційного відновлення сульфату досліджуваними бактеріальними штамами. Усі отримані бактеріальні культури інтенсивно використовували сульфат і лактат, а також продукували гідроген сульфід і ацетат у середовище. Бактерії Desulfovibrio sp., штам Vib-7 утворювали найбільшу кількість (до 3,23 мМ) гідроген сульфіду під час використання приблизно 99\% наявних у середовищі сульфат-іонів. Цей штам також продукував найбільшу концентрацію ацетату (до 15,87 мМ) на п'яту добу культивування. Серед досліджуваних штамів Desulfomicrobium sp. найбільшу концентрацію гідроген сульфіду продукували бактерії Desulfomicrobium sp., штам Rod-9, а найбільшу концентрацію ацетату - бактерії Desulfomicrobium sp., штам Rod-4.

Ключові слова: сульфатвідновлювальні бактерії, Desulfovibrio, Desulfomicrobium, ідентифікація, сульфати, гідроген сульфід.

\section{ИДЕНТИФИКАЦИЯ ШТАММОВ СУЛЬФАТВОССТАНАВЛИВАЮЩИХ БАКТЕРИЙ ТОЛСТОГО КИШЕЧНИКА ЧЕЛОВЕКА}

И. В. Кушкевич

Университет ветеринарных и фрармацевтических наук Брно 1/3, Palackeho, CZ-61242 Брно, Чешская Республика e-mail: ivan.kushkevych@gmail.com

Изолированы сульфатвосстанавливающие бактерии кишечника человека. Эти бактерии идентифицированы как Desulfovibrio sp. и Desulfomicrobium sp. по их морфологическим, ффизиологическим и биохимическим характеристикам, согласно с Определителем бактерий Берджи. Исследован рост этих бактерий при различных условиях, в частности на различных средах, под влиянием кислорода, pH и темпе- 
ратуры. Изучен рост бактерий в модифицированной среде Кравцова-Сорокина и процесс диссимиляционого восстановления сульфата исследуемыми бактериальными штаммами. Все полученные бактериальные культуры интенсивно использовали сульфат и лактат, а также продуцировали гидроген сульфид и ацетат в среду. Бактерии Desulfovibrio sp., штамм Vib-7 образовывали наибольшее количество (до 3,23 мМ) гидроген сульфида при использовании примерно 99\% наличных в среде сульфат-ионов. Этот штамм также продуцировал наибольшую концентрацию ацетата (до 15,87 мМ) на пятые сутки культивирования. Среди исследуемых штаммов Desulfomicrobium sp. наибольшую концентрацию гидроген сульфида продуцировали бактерии Desulfomicrobium sp., штамм Rod-9, а наибольшую концентрацию ацетата - бактерии Desulfomicrobium sp., штамм Rod-4.

Ключевые слова: сульфатвосстанавливающие бактерии, Desulfovibrio, Desulfomicrobium, идентификация, сульфаты, гидроген сульфид.

Одержано: 01.08.2013 